\title{
PUBLIC SERVICE TELEVISION AND CIVIC ENGAGEMENT
}

Daniel Jackson ${ }^{1}$

[to cite this chapter: Jackson, D. (2018). Public service television and civic engagement. In Freedman, D. and Goblot, V. (eds.) A Future for Public Service Television. Goldsmiths University Press, London.]

In most appraisals of democracy today the news media figures prominently. This is for good reason: it is the main channel of communication between elected representatives and citizens; and (self-appointed) watchdog of the powerful. The performance of the news media with respect to civic engagement is thus much debated and often maligned.

While news organizations are sometimes reluctant to accept the responsibility that comes with such power, it is implicit in the core principles of journalistic philosophy, whereby attempts to constrain or censor the news media are seen as threats to democracy itself. ${ }^{2}$ But these normative roles also are surrounded by many tensions that surround the ability of our news media to perform their democratic functions. Borrowing from Bennett and Entman, ${ }^{3}$ I'll discuss four of these tensions.

\section{Tension 1. Diversity versus commonality.}

The media landscape continues to expand rapidly. Media fragmentation and segmentation have expanded the genres of what can be termed 'political'. There is also undoubtedly more news and journalism circulating in the public sphere than ever before, which should be considered a good thing. 
However, segmentation and fragmentation do bring potential dangers as well. Firstly, in a commercially dominated system that is driven by the demands of advertisers, audiences can be segmented by technological access and spending power, not cultural or civic needs. ${ }^{4}$ The resulting risk is that the market disregards some citizens who are less desirable to advertisers. As Gandy 5 explains, the targeting of ever more specialised and smaller groups serves to undercut a common public culture. In this sense, segmentation can be implicitly anti-civic and anti-collectivist.

Secondly, changes in the way we engage with media (increasingly mobile, networked, web-based), together with the affordances of these devices and platforms (e.g. algorithms, data-driven, user-led 'pull mediums') are all pointing in the direction of increased personalisation of our media consumption, including news. This has numerous consequences. Two that I would like to highlight here are that for the interested citizen, there has never been more information available to learn about political issues, but conversely, at the same time it has never been easier to avoid political fare either. Secondly, as research in online news consumption is beginning to show, increasing personalisation in media consumption can lead to ideological homogeneity (also known as a 'filter bubble'), where we consume news that fits within our ideological biases, and can filter out that which doesn't. ${ }^{6}$

The challenge for PSBs is to maintain a sense of shared identity in their offerings, so as to foster a culture that still values civic life. It should also offer moments where audiences can (inadvertently or through choice) be challenged by political views that may contrast with their own. This means that PSBs must offer a range of ideological viewpoints from across the political spectrum. 


\section{Tension 2. The information necessary for citizens to participate effectively in democratic life, versus the entertainment-driven focus of an increasingly commercial-oriented media.}

Here, I will spare readers from the somewhat staid arguments about dumbing down ${ }^{7}$, but instead warn of some other dangers of the increasing corporate and commercial bias of our news media, which emanate from the organisation and structure of the media itself. As profit-seeking entities, commercial media organisations are reliant on advertising as the primary source of their income. As political economists have noted, this dependence can come at the expense of editorial independence. ${ }^{8}$

Whilst many journalists and editors might scoff at such suggestions of advertiser influence, there is growing evidence of other subtle ways in which the relationship between journalism and promotional industries (advertising, marketing and PR) are changing. For instance, a number of recent studies have documented the growing influence of public relations material in the news, raising questions of editorial independence. ${ }^{9}$ Similarly, news organisations - in the search for new income streams - are increasingly working collaboratively with brands through 'branded content' and 'native advertising' initiatives, which blur the lines between news and advertising.

Whilst the response of news organisations to such accusations is often one of defiance, there is no doubt they are still very real threats - to editorial independence, to the normative concept of a fourth estate and in my view, to democracy. I will explain why, with respect to the next tension. 
Tension 3. The need of the media to treat people as citizens on the one hand and as consumer publics on the other.

If we consider the media environment as a whole, there can be little doubt that we are overwhelmingly addressed as consumers rather than citizens. The circulation of goods, the material and symbolic meanings of commodities, and the dominant position of advertising in its many forms make civic culture look diminutive in comparison to consumer culture.

News and journalism are not immune from this process. The consumer model of news is now well established in the UK. ${ }^{10}$ It is precisely because of news organisations' treatment of the audience as consumer and not citizen that some of the processes described above are able to take place.

According to McChesney, the consequences for democracy of a consumercentric news media system are serious, as they carry a huge implicit political bias: 'Consumerism, class inequality and individualism tend to be taken as natural and even benevolent, whereas political activity, civic values and anti-market activities are marginalised.' ${ }^{11}$ The news media are thus central in the definition of culture in terms of consumerism and not citizenship. For him, the combination of neoliberal media policies and corporate media culture tends to promote a deep and profound depoliticisation of society, evidence of which can be seen across the western world, and the USA in particular. In the UK - to the extent that it is not with us already — we should not think we are immune to such developments, especially given recent developments in media policy.

\section{Tension 4. Broadcasters' relationship with the press}


UK news broadcasters are mandated to be impartial, accurate and fair. As such, they provide a counterbalance to a highly partisan press. But this is a delicate balance. Studies consistently show that UK broadcasters are susceptible to following the news agendas of the press. This might not be so problematic if our press were a) not so overwhelmingly right wing and b) concentrated in so few hands. In the recent General Election, we saw a super-charged Tory press, aligned with the agenda of the Conservative Party, that was remarkably successful at setting the news agenda of the terrestrial broadcasters. ${ }^{12}$ Just as worrying was the 2014 survey $\underline{13}$ that found that the UK public holds a number of (quite grave) misapprehensions about many key public policy issues, such as immigration, welfare and crime. Such a collective failure is something our news media, including PSBs, should be ashamed of.

We know what to expect now from the UK press. Therefore it is imperative that public service broadcasters offer us news that is distinctive, independent, and as free as possible from the biases implicit in commercial news and broadcasting.

\section{Conclusion}

Underwriting all of these tensions are the market forces of a largely commercial media landscape. Compared to the US system, British broadcasting has traditionally remained relatively protected from the worst excesses of the market, but this is not inevitable or permanent, especially given the current political landscape.

The $\mathrm{BBC}$ is also not immune from these tensions. Whilst it's news operations have seen relatively fewer newsroom cuts compared to the commercial sector, the BBC arguably acts too much like a commercial broadcaster at times, and news output 
is not always as distinctive or independent as it could or should be. But the question

here is whether the BBC's funding model is driving this type of news, or whether

there are other factors, such as journalistic culture and corporation strategy. I would

argue the latter.

${ }^{1}$ Dr Daniel Jackson is Associate Professor of Media and Communication at Bournemouth University. This is an edited extract from his submission to the Puttnam Inquiry, http://futureoftv.org.uk/wp-content/uploads/2015/12/Dan-Jackson.pdf.

${ }^{2}$ Daniel Jackson, 'Citizens, consumers and the demands of market-driven news,' in Voter as Consumer: Imagining the Contemporary Electorate, eds. Richard Scullion and Darren Lilleker (Cambridge: Cambridge Scholars Publishing, 2007).

${ }^{3}$ Mediated Politics: Communication in the Future of Democracy (Cambridge: Cambridge University Press, 2001).

${ }^{4}$ Robert W. McChesney, 'Corporate Media, Global Capitalism,' in

Media Organization and Production, ed. Simon Cottle (London: Sage, 2000).

${ }^{5}$ Oscar H. Gandy, 'Dividing Practices: Segmentation and Targeting in the Emerging Public Sphere', in Mediated Politics: Communication in the Future of Democracy, eds. W. Lance Bennett, Robert M. Entman (Cambridge: Cambridge University Press, 2000).

${ }^{6}$ Eli Periser, The Filter Bubble (London: Penguin, 2011).

${ }^{7}$ Though you can read some of my thoughts on this and related subjects in Daniel Jackson, 'Citizens, consumers and the demands of market-driven news', in Voter as Consumer: Imagining the Contemporary Electorate, eds. Richard Scullion and Darren Lilleker (Cambridge: Cambridge Scholars Publishing, 2007) and Daniel Jackson, 'Time to get serious? Process news and British Politics', in Retelling Journalism: Conveying Stories in a Digital Age, eds. Marcel Broersma and Chris Peters (Leuven-Paris-Walpole, MA: Peeters, 2014).

${ }^{8}$ For example, Robert Hackett, 'News Media and Civic Equality: Watch Dogs, Mad Dogs, or Lap Dogs?', in Democratic Equality: What Went Wrong? ed. Edward Broadbent (Toronto: University of Toronto Press, 2001), 197-212. See also Edward Herman and Noam Chomsky, Manufacturing Consent: The Political Economy of the Mass Media (New York: Pantheon, 1988).

${ }^{9}$ See Kevin Moloney, Daniel Jackson and David McQueen, 'News journalism and public relations: a dangerous relationship', in Journalism: New Challenges, eds. Stuart Allan and Karen Fowler-Watt. (London: Routledge, 2013); and Daniel Jackson and Kevin Moloney, 'Inside Churnalism: PR, journalism and power relationships in flux', Journalism Studies (2015), 763-780. ${ }^{10}$ See Jackson, 'Citizens, consumers'.

${ }^{11}$ McChesney, 'Corporate Media, Global Capitalism', 36.

${ }^{12}$ Steven Barnett 'Four reasons why a partisan press helped win it for the Tories', in UK Election Analysis 2015: Media, Voters and the Campaign, eds. Daniel Jackson and Einar Thorsen (Bournemouth: The Centre for the Study of Journalism, Culture and Community, 2015); David Deacon, John Downey, James Stanyer \& Dominic Wring, 'News media performance in the 2015 General Election campaign', in UK Election Analysis 2015: Media, Voters and the Campaign, eds. Daniel Jackson and Einar Thorsen (Bournemouth: The Centre for the Study of Journalism, Culture and Community, 2015).

${ }^{13}$ Jonathan Paige, 'British public wrong about nearly everything, survey shows', The Independent, July 9, 2013. http://www.independent.co.uk/news/uk/home-news/british-public-wrong-aboutnearly-everything-survey-shows-8697821.html. 